\title{
WORKING
}

paper

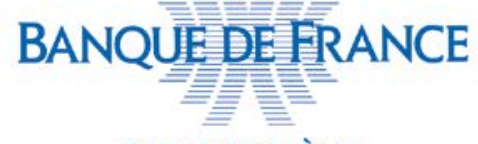

EUROSYSTÈME

\section{External Credit Ratings and Bank Lending}

\section{Christophe Cahn ${ }^{1}$, Mattia Girotti ${ }^{2}$, Federica Salvadè ${ }^{3}$}

\author{
August 2018, WP \#691
}

\begin{abstract}
We study how third-party rating information influences firms' access to bank financing and real outcomes. We exploit a refinement in the rating scale that occurred in France in 2004. The new rules made some firms within each rating class receive a positive rating surprise. We find that such firms enjoy greater and cheaper access to bank credit. In particular, they obtain more credit from previously less informed lenders, and start new bank relationships more easily. Consequently, they rely on equity to a lower extent and invest more. These findings suggest that credit ratings help reducing the hold-up problem and increase competition among banks.
\end{abstract}

Keywords: Credit Ratings, Banks, Lending Technology, Corporate Financing, Real Effects, Holdup problem.

JEL classification: G21, G32.

\footnotetext{
${ }^{1}$ Banque de France, Business Observatory, christophe.cahn@banque-france.fr;

${ }^{2}$ Banque de France, Financial Economics Research division, mattia.girotti@,banque-france.fr;

${ }^{3}$ PSB Paris School of Business, f.salvade@psbedu.paris.

This paper previously circulated with the title "Coarse Credit Ratings, Corporate Financing, and Real Outcomes". We thank Dimitris Andriosopoulos, Kee-Hong Bae, Stijn Classens, Hans Degryse, François Derrien, Falko Fecht, René Garcia, Giorgio Gobbi, William Mullins, Jean-Charles Rochet, and participants at EFMA 2018 Annual Meeting, 2018 AFFI conference, 2018 FINEST Spring workshop, and Banque de France, for helpful comments.
}

Working Papers reflect the opinions of the authors and do not necessarily express the views of the Banque de France. This document is available on publications.banque-france.fr/en 


\section{NON-TECHNICAL SUMMARY}

A potential source of information for credit institutions are credit ratings, which are opinions on borrowers' creditworthiness produced by third-party agencies. Whether banks rely on third-party ratings for their lending decisions is not obvious: Given their superior screening and monitoring technologies, credit institutions may prefer to produce the assessment of borrowers' credit quality on their own. The existing literature typically focuses on the use of credit ratings by capital market investors. Little evidence exists on the use of credit ratings by banks, and their implications for small- and medium-sized firms, which mainly obtain funding through bank debt.

This paper studies whether, and how, rating information influences firms' access to bank financing and corporate policies. To do so, we consider a unique setting in which a large number of small- and medium-sized firms have a credit rating, issued by the Banque de France, and such ratings are primarily available to banks. We then exploit a reform of 2004 that increases the number of notches of the rating scale, making a more stringent and precise classification of firms. The consequence is that within the same rating class some firms receive a positive rating surprise, which implies an increase in their credit rating level, albeit not due to changes in the firms' fundamentals.

Our first hypothesis is that if credit institutions rely on ratings for their lending decisions, such exogenous change in the rating information influences firms' credit availability. To address this question, we exploit firm level information on quarterly bank debt exposure for a panel of firms for which Banque de France's analysts do not report any change in their judgement in the four quarters preceding the reform. When the reform is implemented, some firms receive the rating surprise while others do not. We test our hypothesis using a difference-in-differences methodology, and compare the trajectories of firms that receive the surprise and firms that do not, before and after the reform. We remove any constant firm characteristic, industry-specific business cycle, and rating classspecific dynamics. We find that, exactly when they receive the rating surprise, affected firms experience a greater supply of credit (see the figure below), equivalent to an expansion in the annual flow of bank loans of about $1.2 \%$ of total assets. This finding is consistent with the idea that banks use the third-party certification in their lending decisions.

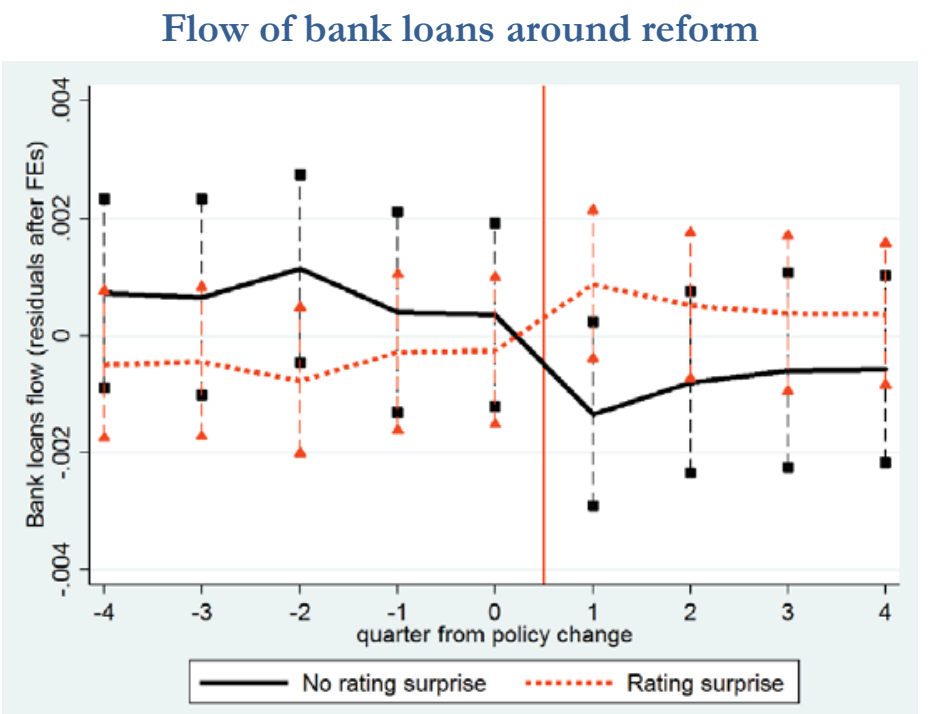

Average residuals (obtained after controlling for time-invariant firm characteristics and industry dynamics) in the quarterly flow of bank loans depending on the distance from the implementation of the reform (solid red line). 
We then test whether the effect of the rating surprise is stronger the less a bank already knows about a borrower. In particular, using a version of the panel at the bank-branchfirm-quarter level, we distinguish across bank-firm relationships along two dimensions. The first dimension refers to the bank's cost of collecting information and monitoring the borrower, right before the reform. The second dimension refers to the incentives that the bank has to gather information and monitor the borrower, right before the reform. All in all, we find that less informed lenders (i.e., banks located far from the borrower, banks with a smaller number of products with the firm, non-main banks, and banks with lower skin in the game) react more strongly to the rating surprise, and adjust their loan supply more. These results indicate that as the third-party information becomes more accurate, the informational gap between lenders that directly collected information and those that did not is reduced. By overall increasing banks' knowledge on borrowing firms, the reform makes borrowers more contestable, and thus increases competition among banks.

The fact that after the rating surprise firms receive greater access to credit from less informed lenders also signals that the reform reduces the hold-up problem. Prior to the reform, better-informed banks could in fact exploit their informational advantage and lockin their customers. However, the information released with the reform helps borrowers to avoid this informational capture. We find confirmation of this by showing that firms receiving the rating surprise have a significantly higher probability to start a new bank relationship. The reform thus enables affected firms to better reveal their quality to new lenders and obtain credit from them, thus reducing the power of incumbent lenders.

We conclude our analysis by showing that the rating surprise is associated with a lower cost of debt of about $15 \mathrm{bps}$, a confirmation of the increase in the firm's ability to reveal its real creditworthiness to lenders. In parallel, we also find that affected firms adjust their funding mix, reducing their reliance on equity relative to firms not receiving the rating surprise. Also, relative to them, they store less cash, invest more, and pay more dividends.

\title{
Cotation externe de crédit et financement bancaire
}

\begin{abstract}
RÉSUMÉ
Nous étudions comment l'information sur l'analyse de risque-crédit produite par une tierce partie influence l'accès des entreprises au financement bancaire et leurs décisions. Nous exploitons un raffinement de l'échelle de cotation produite par la Banque de France qui s'est tenu en France en 2004. En conséquence des nouvelles règles mises en place, certaines entreprises ont bénéficié d'une revalorisation fortuite de leur cote. Nous constatons que ces entreprises profitent d'un accès plus large et moins cher au crédit bancaire. En particulier, elles obtiennent plus de crédit auprès des prêteurs moins bien informés et démarrent plus facilement de nouvelles relations bancaires. Par conséquent, ces entreprises réduisent leur dépendance à l'égard du financement en fonds propres et investissent davantage. Ces résultats suggèrent que les cotations de crédit contribuent à réduire le problème de captation bancaire et à accroître la concurrence entre établissements de crédits.

Mots-clés : cote de crédit, banques, technologie de prêt, financement d'entreprise, effets réels, problème de hold-up.

Les Documents de travail reflètent les idées personnelles de leurs auteurs et n'expriment pas nécessairement la position de la Banque de France. Ils sont disponibles sur publications.banque-france.fr
\end{abstract}




\section{Introduction}

The information on which credit institutions rely for assessing borrowers' credit quality affects lending decisions and, consequently, firms' real outcomes. A potential source of information for credit istitutions are credit ratings, which are opinions on borrowers' creditworthiness produced by third-party agencies. Whether banks rely on third-party ratings for their lending decisions is not obvious: Given their superior screening and monitoring technologies, credit institutions may prefer to internally produce the assessment of borrowers' credit quality (Brealey et al., 1977, Diamond, 1984). In fact, the existing literature focuses on the use of credit ratings by capital market investors, and typically analyzes the effects of ratings for large-sized corporations, which obtain funding through market debt. Little evidence exists on the use of credit ratings by banks, and their implications for small- and medium-sized firms which mainly obtain funding through bank debt.

This paper fills this gap and studies whether, and how, rating information influences firms' access to bank financing and corporate policies. We consider a unique setting in which a large number of small- and medium-sized firms have a credit rating and such ratings are primarily available to banks. These credit ratings are issued by the Banque de France, the French central bank. We exploit a reform of 2004 that increases the number of notches of the rating scale. The new rules make a more stringent and precise classification of firms. The consequence is that within the same rating class some firms receive a positive rating surprise, which is an increase in their credit rating level. Such surprise is not due to changes in the firm's fundamentals.

Our first hypothesis is that if credit institutions rely on ratings for their lending decisions, such exogenous change in the rating information influences firms' credit availability. To address this question, we exploit firm level information on quarterly bank debt exposure. We select a panel of firms for which Banque de France's analysts do not report any change in their judgement in the four quarters preceding the reform. By doing so, we focus on firms that most likely display similar parallel trends up to the reform. When the reform is implemented, some firms receive the rating surprise while others do not. We test our hypothesis using a difference-in-differences methodology, and compare the trajectories of firms that receive the surprise and firms that do not, before and after the reform. We saturate the panel with firm, industry-quarter, and rating-class-quarter fixed effects. In this way, we remove any constant 
firm characteristic, industry-specific business cycle, and rating class-specific dynamics. We find that exactly when they receive the rating surprise, affected firms experience a greater supply of credit. The effect is economically significant: It implies a greater annualized flow of bank loans equivalent to about $1.2 \%$ of (lagged) total assets. This finding is consistent with the idea that banks use the third-party certification in their lending decisions.

That result is, however, silent on the precise mechanism at play. In particular, it does not clarify whether the refinement actually increases banks' knowledge on borrowing firms and ability to assess their credit quality. If that was the case, the effect of the rating surprise should be stronger the less a bank already knows about the borrower. We test this by considering a more granular version of the panel used above, and whose unit of observation is bank-branchfirm-quarter. Using this panel enables us to distinguish across bank-firm relationships along two dimensions.

The first dimension refers to the bank's cost of collecting information and monitoring the borrower, right before the reform. In line with prior studies, we argue that the shorter the distance between the bank branch and the firm's headquarters (Degryse and Ongena, 2005 , Hauswald and Marquez, 2006, DeYoung et al., 2008; Agarwal and Hauswald, 2010), and the larger the number of loan contracts that the firm has with the bank (Mester et al., 2006, Schenone, 2009, Jiménez et al., 2009, Norden and Weber, 2010), the easier and cheaper it is for the bank to access the borrower's information. In those case, banks are thus more informed.

The second dimension refers to the incentives that the bank has to gather information and monitor the borrower, right before the reform. Following the literature on the syndicated loan market (e.g., Lee and Mullineaux, 2004; Sufi, 2007), we argue that the main bank-i.e., the bank that is the main source of funding for the firm - is the lender with the strongest incentives to collect information and monitor the borrower. It is thus better informed on the borrower relative to non-main banks, which free-ride (Carletti et al., 2007). Also the relative importance of a single borrower over the total lent by the bank has implications for the incentives to monitor. Typically, the greater the amount lent to the firm to the total amount lent by the bank, the more the bank has skin in the game and thus incentives to acquire information on the firm.

We employ the usual difference-in-differences methodology, and interact the rating surprise dummy with the measures of bank knowledge just described. We further add bank-quarter 
fixed effects to absorb for bank-specific lending patterns. We find that less informed lenders (i.e., banks located far from the borrower, banks with a smaller number of products with the firm, non-main banks, and banks with less skin in the game) react more strongly to the rating surprise, and adjust their loan supply more. These results indicate that as the thirdparty information becomes more accurate, the informational gap between lenders that directly collected information and those that did not is reduced. In turn, by overall increasing banks' knowledge on borrowing firms, the reform makes borrowers more contestable, and thus increases competition among banks (Hauswald and Marquez, 2003).

The fact that firms receiving the rating surprise obtain more credit from less informed lenders is a signal that the reform reduces the hold-up problem. Prior to the reform, better informed banks could exploit their informational advantage and lock-in their customers (Boot, 2000). However, the information released with the reform helps borrowers to avoid this informational capture. Indeed, we find that the rating surprise is also associated with a higher quarterly probability to start a new bank relationship. The effect is equivalent to an increase of almost 4\%. This is a large effect, especially considering that the quarterly probability of starting a bank relationship is on average equal to $6 \%$. The reform thus enables affected firms to better reveal their quality to new lenders and obtain credit from them, thus reducing the power of incumbent lenders.

We conclude our analysis by studying the effects of the rating surprise on firms' cost of debt and corporate policies. In this case, we employ firms' balance sheet data, which have yearly frequency, but we exploit the usual difference-in-differences methodology. We find that the rating surprise is associated with a lower cost of debt of about $15 \mathrm{bps}$. This is a further confirmation of the increase in the firms' ability to reveal their real creditworthiness to lenders. In parallel, we also find that firms receiving the rating surprise adjust their funding mix, reducing their reliance on equity relative to firms not receiving the rating surprise. Also, relative to them, they store less cash, invest more, and pay more dividends.

An important aspect of our findings is that they are not triggered by the regulatory implications of ratings (see, e.g., Bongaerts et al., 2012, Fraisse et al., 2015, Gropp et al., 2016). The mechanistic reliance on credit ratings as a consequence of rules based on ratings, such as 
Basel II capital requirements, is well documented and a concern for regulators. ${ }^{1}$ In fact, the reform under study realizes because the Banque de France aims to be in line with Basel II requirements. However, we claim that our findings highlight the informational content of ratings rather than the consequence of changes in the capital requirements, for the following reasons. First, Basel II enters into force more than two years after the reform is implemented. Second, the Banque de France is recognized as External Credit Rating Institution only in 2007. Thus, at the time of the reform, Banque de France's credit ratings can not be used to calculate banks' capital requirements. Third, at the time the reform is implemented there is uncertainty on the capital charge related to each rating rating class, and on whether loans to firms which receive a rating surprise bear a greater capital charge than loans to firms which do not receive the rating surprise. Fourth, we find that the rating surprise implies greater access to loans both with maturity up to one year and with maturity more than one year. Only if credit ratings carry an informational content, banks would use them for short-term loans that are repaid before Basel II enters into force.

Overall, this paper highlights one important mechanism for the provision of bank financing. External credit ratings carry an informational content that matters for bank lending decisions. As a consequence, credit ratings become of crucial importance for firms' real outcomes. In doing so, this paper bridges two strands of literature: The first examines the types of bank lending technologies and their effects, while the second focuses on the real effects of credit ratings.

Relative to the first strand of literature, earlier works mainly focus on two types of technologies (Berger and Udell, 2002): Transaction-based lending, under which lending decisions are based on hard information (e.g., credit scoring), and relationship banking, which is based on soft qualitative information acquired by the bank over time. This paper sheds light on a new type of lending technology under which banks (as opposed to investors) rely on both hard and soft information gathered by a third-party certifier. The fact that banks prefer to outsource the assessment of their small- and medium-sized corporate borrowers to rating agencies is a key and novel result: This is surprising especially considering that banks have sophisticated monitoring and certification skills and, unlike rating agencies, have skin in the game. We also

\footnotetext{
${ }^{1}$ Regulators tried to remove rules which triggered mechanistic reliance on ratings for assessments of creditworthiness (see, e.g., section 939A of the Dodd-Frank Wall Street Reform and Consumer Protection Act and Art. 5b(1) Regulation (EU) No 462/2013 of the European Parliament).
} 
add that the use of rating information favors the competition among lenders and reduce the hold-up problem.

Although our research question shares similarities with other studies on the effects of credit scoring on bank lending (Berger et al. 2005), there is an important difference between small business credit scoring and Banque de France's credit ratings. While credit scores are the result of statistical methods applied to financial information, credit ratings also add qualitative information acquired by the rating analyst during meetings with the firm's management. As such, while the increase in competition induced by the use of credit scoring raises concern for the reduction in the use of soft information (Bolton et al., 2016; Hombert and Matray, 2016), the lending technology we highlight still incorporates this information.

In the second of the strands of literature listed above, prior studies show how credit ratings increase the availability of debt (Faulkender and Petersen, 2005; Sufi, 2007), how firms' investment and debt change according to the outstanding rating (e.g., Lemmon and Roberts, 2010, Chernenko and Sunderam, 2011; Almeida et al., 2017), and how more precise Moody's rating information impacts the cost of capital (Kliger and Sarig, 2000; Tang, 2009). We contribute to this literature in several ways. First, while the cited studies mainly consider listed or large-sized firms, which issue bonds to obtain funding, we find that credit ratings are vital for small- and medium-sized enterprises to obtain bank financing. Second, we focus on a new type of ratings issued by a rating agency whose model has not been studied yet. The French central bank, in fact, does not operate under the issuer-paid model. Although its model shares similarities with the investor-paid model, such as the one of Egan-Jones Rating Company (Xia, 2014) and Rapid Ratings (Cornaggia and Cornaggia, 2013), its objective is not to make profits. A recent debate refers to how the agency's business model affects the information quality of the credit ratings (see, e.g., Jiang et al., 2012, Bolton et al., 2012; Stahl and Strausz, 2017). Our analysis does not aim to compare pros and cons of different business models, but suggests that with a rating agency sharing the Banque de France's characteristics, rating information plays a role in the market and may lead to a better allocation of credit. Finally, we show that the existence of a system of credit ratings can increase competition in banking market. However, this system is per se not sufficient to benefit borrowing firms and the economy. It must be that credit ratings are precise enough to distinguish across borrowers. This re-opens the debate on what is the 
optimal level of ratings' granularity and the fact that a rating scale with a continuum of notches might be optimal (Goel and Thakor, 2015).

The paper proceeds as follow. Section II describes the institutional framework underlying the activity of the Banque de France as rating agency and presents a summary of the 2004 reform. Section III describes the data. Section IV presents the empirical results regarding the effects of the rating surprise on firms' access to bank credit, ability to start a new bank relationship, funding mix, and capacity to invest. It also implements a battery of tests to understand if credit ratings are used by banks precisely because of their informational content on firms. Section $\mathrm{V}$ discusses the results and their implications. Finally, Section VI concludes.

\section{Institutional Framework}

\section{A The Banque de France's Credit Rating}

Since its inception, the Banque de France has performed credit risk analysis, but this activity has become particularly important with the creation of the Euro. Monetary and financial institutions can obtain Eurosystem refinancing by pledging as collateral the credit claims that they hold on companies, provided that these have sufficiently high credit ratings. ${ }^{2}$ By assigning credit ratings to firms, the Banque de France thus provides support to the implementation of monetary policy. At the same time, the Banque de France's credit ratings can be used by credit institutions to assess the soundness of potential borrowers, and calculate the capital requirements linked to their corporate loan portfolio so to comply with solvency regulation.

All firms whose headquarters are located in France may, in principle, be rated on the initiative of the Banque de France. ${ }^{3}$ However, in practice only firms with total sales greater than $€ 0.75$ million receive a credit rating. Firms do not pay to be rated by the Banque de France. However, credit institutions pay a fee to access firms' credit ratings.

The access is made possible by the information system of the Banque de France. This was designed primarily to meet the needs of the conduct of monetary policy, but was gradually made accessible to the banking sector. In the period we consider, only French banks have remote access to the database FIBEN (FIchier Bancaire des ENtreprises): This comprises firm

\footnotetext{
${ }^{2}$ At the time of the reform we consider in this paper, bank loans represent around $40 \%$ of the total volume of collateral pledged by French banks for refinancing operations.

${ }^{3}$ In general, all entities without commercial or industrial activities, the State or local governments, and credit institutions are not rated.
} 
level information, including income statement and balance sheet information and firms' credit ratings. As a result, FIBEN constitutes an important source of information for commercial banks and may be used for commercial prospecting and customer risk monitoring.

The Banque de France's credit rating is assigned to firms by pools of analysts, who are based throughout the country, and have expertise in the dynamics of their region. The analysts base their assessment combining hard and soft information. Hard information comprises statistical analysis on accounting and financial data (from tax returns), trade bill payment incident data, bank debt reported by credit institutions (credit register data), and descriptive data on the firm's legal form, managers, location, and so forth. Soft information derives from the interviews conducted by the analysts to the management of each firm. This part of analysis thus involves expert judgment on qualitative elements and forecasts that the manager of the company under study may have communicated.

The rating is updated each time a new element is brought to the attention of the analysts. Revisions happen, in particular, when the statistical analysis highlights significant changes. Firms' financial statements thus constitute the most important input for the assignment of a rating. ${ }^{4}$

Until April 2004, the rating scale comprised four rating levels. From the highest to the lowest, the rating classes were named ' 3 ', ' 4 ', ' 5 ', and ' 6 '. To complete the rating scale, a rating '0' was assigned when the analyst had no information to base its assessment.

\section{$B$ The Reform of the Rating Scale of April 2004}

In the early 2000's, the Basel Committee started to conduct discussions on how to strengthen the soundness and stability of the international banking system. It appeared the need to define a more appropriate measure of the credit risk borne by banks, with particular attention to the quality of the borrowers. The discussions eventually led to the publication of the set of recommendations of June 2004. After further discussions and amendments, the Basel II guidelines were incorporated in two European Union Directives (Directive 2006/48/EC and Directive 2006/49/EC) that entered into force only on July 20, 2006.

\footnotetext{
${ }^{4}$ Filing financial statements and depositing them to commercial courts are mandatory by law. If a firm decides not to deposit its financial accounts, it incurs a fine of $1,500 €$.
} 
At the time of this process, it arose that the Banque de France's rating scale, while methodologically coherent, was too coarse to be used to compute the McDonough ratio, the new solvency ratio suggested by the Basel Committee. Indeed, the firms rated ' 3 ' and '4' accounted for nearly $70 \%$ of the total of the firms rated. As a consequence, the Banque de France decided to adapt its rating scale to fit the requirements imposed by the new regulation. This enabled the Bank to be recognized by banking supervisors as an External Credit Assessment Institution (ECAI) in 2007.

The investigations to adapt the rating scale started in 2002. After several contacts with the banking supervisor, it was decided that the methodological changes would be very limited, and the rating scale would keep its global structure. It was also decided that the new ratings would be assigned under the same information set of the old ratings. The new rating scale was presented to the supervisory authorities and to the representatives of the French banking sector, and was finally approved by the Banque de France at the end of 2002. In 2003, the Banque de France's analysts were trained on how to rate firms based on the new rating scale. In the first quarter of 2004, firms were rated according to both scales to perform comparative analysis, but only the old ratings were disclosed. Only in April 2004, the new rating scale was officially announced by the Banque de France, and firms appeared rated accordingly.

The reform of the rating scale consisted in a refinement of the original rating classes, and in the introduction of three new rating levels accounting for different frequencies of default on trade bills. Figure 1 illustrates the changes that occurred during the refinement process. After the reform, the rating scale includes eleven positions. Rating class ' 3 ' is split into three new subcategories labelled ' $3++$ ', ' $3+$ ', and ' 3 ', rating class ' 4 ' is split into two new subcategories labelled ' $4+$ ', and ' 4 ', and rating class ' 5 ' is split into two new subcategories labelled ' $5+$ ', and ' 5 '. This implies that when the reform is implemented firms in the new subcategories ' $3++$ ', ' $3+$ ', ' $4+$ ', and ' $5+$ ' appear to benefit from an exogenous increase in their rating level-i.e., a positive rating surprise - relative to firms in the subcategories ' 3 ', '4', and ' 5 '.

To achieve the rating scale refinement, the analysts elaborated finer rules to distinguish across firms. Specifically, within each rating class, the new methodology introduced new thresholds for selected financial ratios. For example, the equity ratio, the EBIDTA margin, and the Banque de France's credit score. The Banque de France's credit score is an estimation of the 
firm's probability of failure over a 3-year horizon. It is computed by applying an internal model of the Banque de France on the basis of hard information such as level and cost of financial debt, balance sheet structure, profitability, solvency and growth (see Bardos, 1998; Avouyi-Dovi et al., 2009). The higher the score, the higher is the firm's probability of default.

Clearly, the higher the equity ratio and the EBIDTA margin, and the lower the Banque de France's score, the better the firm's creditworthiness. Thus, firms falling above the established thresholds for the equity ratio and the EBIDTA margin and below the threshold for the Banque de France's score were more likely to receive the rating surprise at the moment the reform was implemented. However, the thresholds were only a benchmark and the assignment of the rating surprise was not mechanical. Each analyst could decide to assign the rating surprise even if the firm's financial ratios fell below or above the relevant thresholds. Such decision could be based on the soft information the analyst obtained, but had to be justified and motivated.

To sum up, an important aspect of the reform is that the positive rating surprises-i.e., the ' + ' or the ' ++ ' - were due to the exogenous change (refinement) in the Banque de France's opinion and did not depend on changes in the firms' fundamentals.

On another note, firm loans' eligibility as collateral in Eurosystem refinancing operations was not altered by the rating reform: all firms which were eligible remain eligible after the reform. In fact, as described by Cahn et al. (2017), and Mésonnier et al. (2017), changes in the eligibility of the (loans to) firms may influence the loan supply of credit institutions.

\section{Data}

Our empirical analysis exploits two main datasets, all contained in the FIBEN database. The first is the Service Central des Risques dataset, which is the French credit register. The second is FIBEN Bilans, which includes firm level balance sheet and income statement information.

The credit register is directly operated by the Banque de France, and collects bilateral credit exposures between resident financial institutions and non-financial corporations. A bank reports individual credit exposures of all its client firms when the total exposure per firm is larger than $€ 76 \mathrm{~K}^{5}$

\footnotetext{
${ }^{5}$ Total exposure includes drawn and undrawn credit, as well as guarantees granted by the bank.
} 
In our baseline analysis, we collapse the register to have a firm-quarter unit of observation. We construct four variables: the quarterly flow of total bank loans, the quarterly flow of loans with maturity up to one year, the quarterly flow of loans with maturity greater than one year, and the new bank relationship dummy. The first three variables are defined as the quarterly change in the amount of bank debt, respectively short-term bank debt and long-term bank debt, normalized by lagged total assets. Firms' total assets are recovered from the balance sheet data described in the following. ${ }^{6}$

The new bank relationship dummy variable takes the value of one at any occurence of a new bank-firm relationship for a given firm. A potential pitfall of this dummy variable comes from the fact that the credit register only reports exposures greater than $€ 76 \mathrm{~K}$. Thus, the first occurence of a bank-firm link in the data may not be the actual first occurence of the relationship. It might be that a relationship is old but the exposure has been very small until a certain quarter, at which point it is recorded in the credit register. The interpretation of the results should take this possibility into account.

Our analysis also exploits the heterogeneity existing across bank-firm relationships. In that case, we consider an uncollapsed version of the credit register data. The unit of observation becomes bank-branch-firm-quarter. In this way, we can construct measures of the knowledge that a given bank has on a firm.

We use balance sheet and income statement data when we analyze the effect of the rating surprise on firms' cost of debt and real outcomes. ${ }^{7}$ From this dataset, we extract the following variables. The yearly flows of bank debt, equity, and cash, obtained as yearly changes in the variable of interest, normalized by lagged total assets. The loan rate, obtained as interest payments divided by financial debt. The yearly investment, computed as the yearly difference in tangible assets (mainly property, plant, and equipment), normalized by lagged total assets. The unit of observation of the balance sheet panel is firm-year.

We merge the credit register and balance sheet panels with the firms' 3-digit industry code. Moreover, we merge the balance sheet panel with the firms' credit score information.

\footnotetext{
${ }^{6}$ Since the balance sheet data have yearly frequency, the normalization of the quarterly changes in the amount of bank debt is done with respect to the total assets appearing in the last balance sheet available at the time the observation refers to.

7FIBEN Bilans includes firms' financial statements only when the firm's turnover exceeds $€ 0.75$ million. This threshold does not harm our analysis because Banque de France rates all firms above it. Still, since this cutoff is relatively low, this dataset mainly includes small- and medium-sized enterprises (but not sole entrepreneurs and micro enterprises).
} 
Our empirical analysis focuses on rating classes ' 3 ', '4', and ' 5 '. Our cleaning strategy works as follows. In the samples based on the credit register data, firms are tracked from four quarters before the policy change to four quarters after it. We select firms that in the four quarters before the implementation of the reform stay within the same rating class (i.e., either class ' 3 ', '4', or '5'), and for which Banque de France's analysts do not report any change in their judgement. By doing so, we ensure that there are no appreciable changes in firms' fundamentals and firms are likely to follow a similar parallel trend prior to the reform. After the reform, some firms receive the rating surprise, while others do not.

In the sample derived from the balance sheet data, firms are tracked from two years before the policy change to the first year after it. Similarly to before, we retain firms that in the two years before the reform belong to the same rating class and for which Banque de France's analysts do not report any change in their appreciation. We also impose that until the reform selected firms do not have a significant change in their Banque de France's credit score. ${ }^{8}$ As before, these conditions ensure that there are no appreciable changes in firms' fundamentals before the policy change and firms are likely to follow a similar parallel trend.

Table I provides the summary statistics of the baseline credit register sample (first four rows in each panel) together with the balance sheet sample (subsequent rows). The table reports the statistics separately for each rating class. Firms in rating class ' 3 ' are typically larger and older, with average total assets of about $€ 8.6$ millions. In any case, the 95 th percentile of the distribution of total assets is below $€ 15$ millions, indicating the small- and medium-sized nature of the firms in the sample. As expected, going from rating class ' 3 ' to rating class ' 5 ' (i.e., going from better-rated to worse-rated firms) firms' profitability and capitalization decrease. Also, the Banque de France's score increases, confirming that firms in rating class ' 5 ' have a higher probability of failure.

\section{Results}

The main question we ask is whether, and how, banks use third-party credit ratings for their lending decisions. Our hypothesis is that credit ratings carry an important informational

\footnotetext{
${ }^{8}$ In fact, we could not impose this condition in the credit register sample since the release of the the Banque de France's credit score happens yearly, when the balance sheet is reported. This implies that in the four quarters before the policy change, which is the period considered as pre-reform in the credit register sample, most firms have only one value of score available.
} 
content for banks, and help them screening borrowers. We test this hypothesis by studying the effects of the 2004 rating scale reform on firms' access to bank credit. We first look at whether firms that receive a rating surprise benefit from greater loan supply after the reform. Then, we implement a battery of tests to understand if credit ratings are used by banks precisely because of their informational content on firms. Finally, we show the implications of credit ratings for firms, in terms of ability to start a new bank relationship, funding mix, and capacity to invest.

\section{A Do Banks Use The Third-Party Credit Ratings For Their Lending Decisions?}

We start our analysis by focusing on the first of the margins mentioned above: we study if firms that receive a rating surprise have more bank credit offered. In principle, the reform discloses that such firms are relatively better, thus pushing banks to revise their information sets and loan supply schedules. However, the rating surprises might have limited content for banks. The reason is that banks have a superior screening technology, and may have already distinguished across firms within each rating class before the reform. According to this alternative hypothesis, the rating surprises are redundant information for banks.

As a first pass at testing these two competing hypothesis, we conduct a graphical analysis on what are the effects of the 2004 reform on firms' access to bank credit. We consider the quarterly data on firms' bank debt exposures. The relatively high frequency of this dataset enables us to precisely time the changes in firms' credit supply, and see if they relate to the implementation of the reform. As already described in Section [II] we focus on the period that goes from five quarters before the reform to four quarters after it. The rating classes considered are class ' 3 ', class ' 4 ', and class ' 5 '. Within each rating class, the reform assigns some firms a rating surprise (either the '+' or the ' ++ '). We group firms depending on whether after the reform they receive the rating surprise or not. We regress the quarterly flows of bank loans over firm and industry x quarter fixed effects, and take the average of the resulting residuals within each group of firms and quarter.

Figure 2 plots the dynamics for the two groups of firms. The group of firms that will not receive the surprise are defined by the solid black line. The group of firms that will receive the rating surprise are described by the dotted red line. The vertical red line identifies the implementation of the reform. The figure shows that up to the implementation of the reform, 
the two groups have very similar parallel dynamics. However, exactly when the reform is implemented, firms that receive the rating surprise have a rapid increase in the bank credit offered, especially with respect to firms that do not receive the rating surprise. This preliminary evidence suggests that banks base their loan supply decisions on the third-party credit ratings.

We provide an econometric counterpart to the graphical analysis just presented. We structure a difference-in-difference model that writes:

$$
\frac{{\text { bank loans } \text { flow }_{j q}}_{\text {total asset }_{j q-1}}=\beta \text { rating surprise }}{j q}+\eta_{\text {industry }_{j} ; q}+\eta_{\text {rating }_{\text {class }} ; q}+\eta_{j}
$$

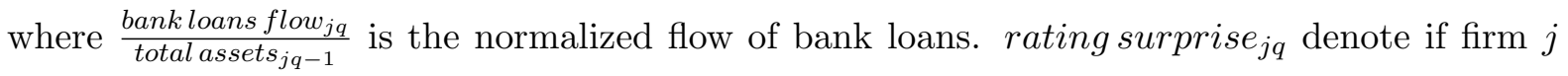
has received the rating surprise at quarter $q . \eta_{\text {industry }_{j} ; q}$ identifies industry-quarter fixed effects, $\eta_{\text {rating }_{\text {class }} ; \text {; }}$ identifies rating-class-quarter fixed effects, while $\eta_{j}$ is the firm fixed effect.

The parameter of interest of equation (1) is $\beta$. It captures the effect of receiving the rating surprise on the credit supply to the firm. Its identification works by comparing firms that following the rating scale reform receive the rating surprise, with firms that do not. Note that the rating surprise does not depend on changes in the firm's fundamentals, but it is due purely to the refinement of the rating scale.

Importantly, we saturate the model with a set of fixed effects. Industry-quarter fixed effects control for differences across industry dynamics. Rating-class-quarter fixed effects control instead for differences in the dynamics between rating classes. Including them implies that the effect of the rating surprise is identified within each rating class, by comparing firms that receive the surprise with those that do not. Finally, firm fixed effects control for firm characteristics that are not time-varying in the period analyzed.

Table II] first column, reports the estimated coefficients. We find that following the implementation of the reform, firms that receive the rating surprise experience a greater supply of bank credit. The effect is economically significant: it implies a greater annualized flow of bank loans equivalent to about $1.2 \%$ of lagged total assets. The exogenous rating surprises are not redundant information: banks do take them into account when they supply credit.

These results are however silent on the precise mechanism that relates the rating surprise with the greater loan supply. Our hypothesis is that credit ratings carry an informational content on the firms. Therefore, when firms receive the ' + ' or the ' ++ ', banks learn something 
positive and new about them, and provide more credit. The following subsections present a battery of tests to characterize whether this is actually the case.

\section{A.1 Do Banks Learn About Borrowers From The Third-Party Credit Ratings?}

One mechanism alternative to the informational content of ratings refers to the fact that the 2004 rating reform is implemented by the Banque de France to comply with future Basel II requirements. It might be that the rating surprises alter banks' loan schedules because banks anticipate that loans to firms which receive the rating surprise will have lower capital charges when Basel II requirements become operational.

This alternative hypothesis has, however, severe limitations. First, as described above, Basel II requirements enter into force only on July 20, 2006, which is more than two years past the implementation of the rating reform. It is thus unlikely that banks select firms based on an event relatively far in the future. Second, in 2004, it is not clear that the Banque de France would later become ECAI. So, at that time, there is a non-negligible probability that its ratings would not be useful to calculate the capital charges in the future. Third, in 2004, there is uncertainty on the precise capital charge that each new notch implies under Basel II. As a consequence even if a firm receives a rating surprise, it may end up having the same capital charge of a firm that does not receive a rating surprise.

Nevertheless, we can rule out the hypothesis based on banks anticipating Basel II requirements by studying whether our results depend on the maturity of the loans considered. If our earlier results depend on banks anticipating Basel II capital charges, the effects should be mainly with loans of longer maturity. Only in those cases, in fact, the bank still has loans lent in 2004 on its balance sheet when Basel II requirements enter into force. Alternatively, if credit ratings have an informational content and the reform leads to a flow of new information to banks, the effects should be even across loans with different maturity.

The credit register data distinguishes loans with maturity up to one year from loans with maturity greater than one year. We study the effect of the rating surprise on the flows of loans in these two categories using equation (1). The second and third columns of Table II report the estimated coefficients. The rating surprise leads to greater flows of both short term and long term bank loans. The fact that the rating surprise implies a greater flow of loans with maturity 
up to one year rules out the mechanism with banks anticipating Basel II requirements. Rather, it favors the idea that the reform increases banks' knowledge on borrowing firms.

What these results do not dismiss refers to the fact that the credit ratings under study are produced by the central bank: Even if the French central bank has no direct supervisory power on the banking system, its ratings may have a disciplining effects on credit institutions and be taken as benchmark to measure firms' credit quality. After the implementation of the reform, credit institutions may thus be more willing to lend to firms that receive the rating surprise as these are certified by the Banque de France to be relatively better. This scenario is alternative to the one that hypothesizes that the rating reform increases banks' knowledge on borrowing firms. The following Subsection tests which mechanism is actually at play by studying in what cases banks adjust their loan supply following a rating surprise, and so when they do use the external credit ratings.

\section{A.2 When Do Banks Use The Third-Party Credit Ratings?}

We analyze when the rating surprise has stronger bite on lending decisions (i.e., in what cases banks make greater use of the external credit ratings). Under the disciplining hypothesis sketched above, banks should shift their loan supply for all firms that receive the rating surprise, and the effects should be uniform across bank-firm relationships. Conversely, under the hypothesis that the reform increases banks' knowledge on borrowing firms, the effect should be stronger the less a bank already knows about a firm.

We consider the uncollapsed version of the credit register data and we keep as unit of observation the bank-branch-firm-quarter. We keep all bank-firm relationships existing right before the policy change. We measure the knowledge a bank has on a given firm by two dimensions. First, the bank's screening and monitoring cost: proxies include the geographical distance between the bank branch and the firm's headquarters, and the number of loan contracts the bank has with the firm. Second, the incentives the bank has to screen and monitor the firm: proxies include the proportion of lending given by that particular bank to the total borrowed by the firm, whether that bank is the main bank for the firm, and the proportion of lending to that firm to the total amount lent by the bank.

We expect that the greater the distance between the bank branch and the firm, the harder 
it is for the bank to screen and monitor the firm, and the less the bank knows about the firm. Conversely, the larger the number of loan contracts through which the firm borrows, the more the bank monitors if the firm repays each loan in due time, and the greater the knowledge it accumulates on the firm. As for the second set of measures, when the firm borrows from a pool of lenders, the non-main lenders may free-ride on the main lender for monitoring. Thus, the lower the proportion of lending given by the bank to the total borrowed by the firm, the greater the incentives of the bank to free-ride and not monitor the firm, and the less the bank learns about the firm. On the opposite, the main bank does not free-ride, and accumulates more information on the firm. Finally, the greater the lending to the firm to the total amount lent by the bank, the more the bank has skin in the game and incentives to monitor the firm, and therefore the more the bank knows about the firm.

We use the same difference-in-differences model used in the baseline regression, and interact the rating surprise dummy with the following proxies. 'bank branch is located in a diff. town' indicates if the firm is headquartered in a different town than where the bank branch is located. ' $\mathrm{N}$ products with the bank' is the number of loan products (e.g., leasing contracts, mortgages, etc.) that the firm has with the bank. 'bank importance in the pool of lenders' is the proportion of bank debt borrowed from the bank over the total borrowed. 'main bank' is a dummy variable that equals 1 when the previous proportion reaches the highest level across the relationships the firm has. Finally, 'firm importance in the pool of borrowers' denotes the proportion of bank debt that the firm obtained relative to the total amount of debt lent by the bank. We run the regressions including bank-quarter fixed effects so to capture any bank-quarter specific shock that may affect a bank's loan supply.

Table III reports the estimated coefficients for what relates to the measures of the bank's screening and monitoring cost. The rating surprise has stronger effects the greater the distance between the bank branch and the firm-i.e., when the the firm is headquartered in a different town than where the bank branch is located - and the fewer the number of borrowed loan contracts. This indicates that the rating surprise has stronger bite when, until the reform, the cost to screen and monitor is higher, and so when the bank has less information on the firm.

The results on the measures of the bank's incentives to screen and monitor are in Table IV. The first two columns, which report the effects of 'bank importance in the pool of lenders' and 
'main bank', are based on the sample of firms that borrow from more than one bank at the same time. This is to avoid the non-interesting cases in which there is no pool of lenders but just one bank. The estimated effects indicate that the lower the bank's incentive to screen, and thus the less the bank knows the firm, the stronger are the effects of the rating surprise.

Overall, both Table III and Table [IV] reject the mechanism based on Banque de France's ratings disciplining banks' lending decisions. Rather, they lead to the idea that the rating reform increases banks' knowledge on firms: Since banks learn something new especially when they have little prior information, it is in those cases that their loan supply schedules changes the most.

The evidence provided so far indicates that: i) Banks use the third party ratings for their lending decisions, ii) Credit ratings increase banks' knowledge on firms, and iii) Banks use the credit ratings particularly when their prior information is modest. Given this, the next subsection focuses on the firms' side and studies how the rating surprise affects corporate policies.

\section{$B$ The Effects of Third-Party Credit Ratings On Corporate Policies}

\section{B.1 Probability of Starting a New Bank Relationship}

The results of the previous Subsection indicate that it is the non-main banks that adjust the supply the most following the rating surprise. This is suggestive of the fact that the rating surprise reduces the hold-up problem. In general, because the main bank has a lot of information on the firm, it has the ability to charge higher rates, which result in less quantity borrowed. Our findings claim that when the firm receives the rating surprise, there is a flow of information to other lenders, and the power of the incumbent bank decreases. The results of Table $\mathrm{V}$ are derived from bank-firm relationships existing before the rating reform, and can be considered as an intensive-margin of this mechanism. The extensive margin entails the ability to start new bank relationships.

We study if the rating surprise affects firms' ability to start new bank relationships. We tackle this question using the following conditional fixed effects Logit model:

$$
\operatorname{Pr}\left(\text { new bank } \text { rel }_{j q}=1 \mid \cdot\right)=\Lambda\left(\gamma \text { rating } \text { surprise }_{j q}+\eta_{q}+\eta_{j}\right)
$$


where new bank rel $_{j q}$ is a dummy that takes the value of 1 when firm $j$ starts a new bank relationship (as defined in Section III) in quarter $q . \Lambda$ is the Logistic function, rating surprise $j q$ denotes if firm $j$ has received the rating surprise at quarter $q, \eta_{q}$ identifies quarter fixed effects, while $\eta_{j}$ is the firm fixed effect.

Estimating the parameters in the conditional Logit requires that there is variation in the dependent variable within each firm. This means that we have to focus on firms that start at least one bank relationship in the period that goes from five quarters before the reform to four quarters after it. Since considering only those firms might be restrictive, we also estimate the effects of interest through a linear probability model. That model does not require variation in the dependent variable and relates new bank rel $_{j q}$ to the independent variables above in a linear fashion.

We present the results in Table $\mathrm{V}$. We find that the rating surprise leads to an increase in the probability of starting a new bank relationship. This result holds with both the conditional Logit and the linear probability model. In terms of magnitude, the rating surprise leads to a greater probability of almost $4 \%$ (as obtained from the conditional Logit). This is a large effect, especially considering that the quarterly probability of starting a bank relationship is on average equal to $6 \%$.

These results corroborate the idea that the third-party credit ratings ease the hold-up problem. Not only firms have a greater supply of loans from existing banks, but they also have a greater ability to start new bank relationships. The reason is that credit ratings carry valuable information on firms for banks, thus reducing the cost of screening prospective borrowers.

The remaining questions include how credit ratings affect the cost of bank debt, and more generally corporate policies. For instance, given the greater access to bank credit following the rating surprise, how do firms compose their funding mix? Do they invest more?

\section{Cost of Bank Debt, Funding Mix, and Investment}

We investigate how the rating surprise affects the cost of bank debt, the funding mix, and the investment. Unfortunately, the analysis of these variables can be conducted only at yearly frequency, when firms report their balance sheet. 
Measuring the effect of the rating surprise on the cost of bank debt complements the effects on bank credit supply. We thus start by a graphical analysis similar to the one done in Subsection $A$. We focus on the period that goes from two years before the reform to the first year that follows. We group firms depending on whether after the reform they receive a rating surprise or not. We regress the loan rate over firm and industry x quarter fixed effects, and take the average of the resulting residuals within each group of firms and year.

Figure 3 plots the dynamics of the two groups. As in Figure 2, the group of firms that will not receive the surprise is defined by the solid black line, while the group of firms that will receive the rating surprise is described by the dotted red line. The vertical red line identifies the implementation of the reform. Up to the implementation of the reform, the two groups have similar parallel dynamics. When the reform is implemented, however, firms that receive the rating surprise have a marked decrease in the loan rate paid, especially with respect to firms that do not receive the rating surprise. This is suggestive that the reform not only acted on the quantity of credit but also on its price.

We now more formally explore the effects of the rating surprise on the loan rate, but also on the yearly flows of bank loans, equity, and cash, normalized investment, and dividends paid, based on model (1). However, in this case, the data have yearly frequency, and we consider firms from two years before the reform to the first after it. Note that the reason we still look at the flow of bank loans is for robustness. In fact, balance sheet data report the actual total amount of loans borrowed, and not only the sum of those above the threshold of $€ 76 \mathrm{~K}$, as it results using the credit register data.

We present the estimation results in Tables $\mathrm{VI}$ and VII. The estimates confirm that the rating surprise is associated with a lower loan rate paid. The effect is of the order of 15 basis points. This confirms prior graphical evidence that the reform not only acted on the quantity of credit but also on its price. In fact, Table VI corroborates the results on the quantity of loans presented earlier. The rating surprise is related to a greater yearly flow of bank loans, with a magnitude consistent with the one presented in Subsection $A$ obtained exploting the quarterly credit register data.

The greater and cheaper access to bank credit has important consequences on firms' funding mix and investment. First, the rating surprise leads to a lower reliance on equity as a funding 
source. In fact, for every extra dollar received from bank loans, there is an equal reduction in the flow of equity. Also, the rating surprise leads to less cash stored and, correspondingly, greater investment. Finally, it also leads to a greater distribution of dividends.

Our interpretation is that once credit becomes more available, there is less need to obtain financing through equity and keep precautionary amounts of cash to be used in case of need. Rather, the firm has more ability to invest and remunerate equity holders. Overall, these results clarify the importance of external credit ratings in affecting corporate policies.

\section{Discussion}

Our findings indicate the importance of external credit ratings in lending decisions, especially in those cases in which banks have limited information on the borrowing firms. Since credit ratings are available in FIBEN together with other firm level information, a central question refers to what additional information credit ratings carry relative to what an analysis of available hard information (e.g., financial ratios) provides. This question can be further detailed as: Was the rating surprise predictable based on firms' fundamentals? Do banks react to the rating surprise because this discloses positive soft information?

We provide an answer to the first question by checking to what extent the firms receiving the rating surprise could be identified in advance by banks using the information available on the FIBEN database. We compare firms that later receive the rating surprise with later unaffected firms, right before the reform. This comparison is done within each rating class, and is based on the following firm characteristics: equity over total assets, tangible assets over total assets, cash over total assets, return on assets, Banque de France's score, and log total assets.

The results are in Table VIII. Within the three rating classes, the firms that later receive the rating surprise have a higher return on assets and a lower Banque de France's score relative to later-unchanged firms. This suggests that they are more profitable and less risky. Their greater creditworthiness could thus be identified by banks before the reform, at least to some extent. However, since these firms obtain more and cheaper credit exactly at the time of the rating surprise, our results claim that banks did not identify them in advance.

Table VIII seems to suggest that our results especially derive from banks that use the credit ratings as main input and that do not process other available information. This is not surprising. 
In fact, our findings also indicate that the greater loan supply comes in particular from banks that have limited incentives to screen the borrowing firms in the first place. In those cases, banks do not screen the borrower thoroughly. This means that they may react to positive news only when this is simple to process and access. That is, for example, a positive surprise in the credit rating.

To provide an answer to the second of the questions asked above, and better characterize what additional information the rating surprises carry, we repeat part of our analysis using a propensity score matching methodology (instead of the baseline difference-in-differences methodology). The idea is to check if across firms with similar observable fundamentals, those receiving the surprise experience greater and cheaper loan supply than those not receiving it. Since their fundamentals are similar, what changes between them is either the simple fact of appearing with the rating surprise and thus looking better than firms which do not receive it, or unobservable positive soft information that makes the first receiving the rating surprise, or both.

The metric to measure similarity across firms is the propensity score. This is function of the following before-the-reform characteristics: size (as proxied by log total assets), leverage (equity over total assets), Banque de France's score (representing the probability of failure in the subsequent three years), industry, and rating class. The matching procedure is done with replacement, which means that each firm that does not receive the rating surprise can be used as a neighbor for several 'treated' firms, which receive the surprise. We take the closest five firms not receiving the rating surprise as control for each treated firm receiving the surprise.

We then study the effect of the rating surprise on different outcome variables: the change in the normalized flows of bank loans, equity, and cash, the change in normalized investment and dividends, and the change in the loan rate. Such changes are obtained by differencing the values of the variables of interest before and after the reform. By looking at the changes, the effect of the rating surprise we measure is on the dynamics of the variable of interest rather than on its level, and it has the same interpretation of the difference-in-difference estimates obtained including firm fixed effects.

The resulting estimates appear in Tables $\mathrm{IX}$ and $\mathrm{X}$. The effects are very similar to those obtained in the difference-in-differences regressions. Similar firms before the reform have dif- 
ferent outcomes after the reform, and this depends on whether they receive or not the rating surprise. These findings have two implications. First, they suggest that our difference-indifferences results were not driven by differences in trends due to firms' fundamentals before the reform. Second, we cannot rule out that banks react to the rating surprise because it makes the firms' fundamentals being more easily processable by banks or because it discloses positive soft information.

Both mechanisms are consistent with the findings of Section IV] On the one hand, banks with lower incentives to screen a borrower may react more to the rating surprise because this is simple to process and access, even if it is mainly a repackaging of available hard information. On the other hand, the soft component of the rating surprise may be the first motive of reaction of banks located far away from the borrower, which have lower ability to collect soft information (Degryse and Ongena, 2005; Agarwal and Hauswald, 2010).

Having characterized which banks react to the rating surprise and what this discloses to them is important to derive the policy implications. One policy concern is that because they have the possibility to use the Banque de France's credit ratings to screen borrowers, banks become 'lazy'. What we show is that it is especially banks with limited incentives to screen firms to react to the rating surprise. These banks choose not to gather thorough information and absent the reform they would be less informed. Thus, even if these banks over-rely on these ratings, the reform increases their knowledge, and this is a positive effect.

On another note, we can argue that credit ratings on small- and medium-sized firms help reducing the informational gap between banks. In effect, a major result of this paper is that external ratings decrease the power of incumbent lenders and increase bank competition. This increase in competition differs from the one induced by the use of credit scoring, or more broadly, by technological progress (Hauswald and Marquez, 2003; Berger et al., 2005; Sutherland, 2018). Such studies document that as technology improves, banks increase the use of transaction lending. But this implies a reduction in the use of soft information and thus the loss of its benefits (Bolton et al., 2016; Hombert and Matray, 2016). In our case, instead, since credit ratings are a combination of both hard and soft information, the induced increase in competion does not come at the cost of the disappearance of soft information.

Finally, DeYoung et al. (2008) show that greater credit supply may be triggered by loans to 
riskier borrowers. This is not the case in our setting. Indeed, the greater supply is targeted to firms receiving the rating surprise, which are firms with better creditworthiness. In fact, Table VIII indicates that firms that subsequently receive the rating surprise have a smaller flow of bank debt, and rely overall more on equity as a funding source, right before the reform. We thus argue that the refinement of the rating scale allowed to reach a better allocation of credit with important effects on the firms' real outcomes. In this sense, we shed light on a bright side of the banks' reliance on credit ratings.

To conclude, the existence of a system of credit ratings is per se not sufficient to benefit borrowing firms and the economy. It must be that credit ratings are precise enough to distinguish across borrowers. This opens the debate on what is the optimal level of ratings' granularity and the fact that a rating scale with a continuum of notches might be optimal (Goel and Thakor, 2015).

\section{Conclusions}

We study how rating information influences firms' access to bank credit and corporate policies. We consider a unique setting in which a large number of small- and medium-sized firms have a credit rating issued by the Banque de France, the French central bank. Such ratings are mainly available to credit institutions. We exploit a reform that increases the number of notches of the credit rating scale. The consequence is that within the same rating class some firms receive a positive rating surprise, despite not having changes in their fundamentals.

Consistently with the hypothesis that banks base their lending decisions on the third-party ratings, we find that firms receiving the rating surprise enjoy greater and cheaper access to bank credit. In particular, we find that such firms receive more credit from previously less informed banks, such as banks located far from the firm and non-main banks. In addition, these firms are also more likely to start new bank relationships. These results suggest that external rating information can reduce the hold-up problem and increase bank competition.

We also investigate the effect of the rating surprise on corporate policies. We find that firms receiving the rating surprise rely less on equity, store less cash, invest more, and pay more dividends relative to unaffected firms. 
Overall, this paper highlights the importance of external credit ratings for the provision of bank financing. We show that lenders' reliance on this information can have important consequences for borrowers' real outcomes and the competition among lenders. 


\section{References}

Agarwal, Sumit and Robert Hauswald, "Distance and private information in lending," The Review of Financial Studies, 2010, 23 (7), 2757-2788.

Almeida, Heitor, Igor Cunha, Miguel A Ferreira, and Felipe Restrepo, "The real effects of credit ratings: The sovereign ceiling channel," The Journal of Finance, 2017, 72 (1), 249-290.

Avouyi-Dovi, Sanvi, Bardos Mireille, Caroline Jardet, Ludovic Kendaoui, and Jérémy Moquet, "Macro stress testing with a macroeconomic credit risk model: Application to the French manufacturing sector," Working Paper 238, Banque de France 2009.

Bardos, Mireille, "Detecting the risk of company failure at the Banque de France," Journal of Banking \&f Finance, 1998, 22 (10), 1405-1419.

Berger, Allen N and Gregory F Udell, "Small business credit availability and relationship lending: The importance of bank organisational structure," The Economic Journal, 2002, $112(477)$.

_, W Scott Frame, and Nathan H Miller, "Credit scoring and the availability, price, and risk of small business credit," Journal of Money, Credit and Banking, 2005, pp. 191-222.

Bolton, Patrick, Xavier Freixas, and Joel Shapiro, "The credit ratings game," The Journal of Finance, 2012, 67 (1), 85-111.

_, _, Leonardo Gambacorta, and Paolo Emilio Mistrulli, "Relationship and transaction lending in a crisis," The Review of Financial Studies, 2016, 29 (10), 2643-2676.

Bongaerts, Dion, KJ Cremers, and William N Goetzmann, "Tiebreaker: Certification and multiple credit ratings," The Journal of Finance, 2012, 67 (1), 113-152.

Boot, Arnoud WA, "Relationship banking: What do we know?, Journal of financial intermediation, 2000, 9 (1), 7-25.

Brealey, Richard, Hayne E Leland, and David H Pyle, "Informational asymmetries, financial structure, and financial intermediation," The journal of Finance, 1977, 32 (2), 371387.

Cahn, Christophe, Anne Duquerroy, and William Mullins, "Unconventional Monetary Policy and Bank Lending Relationships," Working Paper 659, Banque de France 2017.

Carletti, Elena, Vittoria Cerasi, and Sonja Daltung, "Multiple-bank lending: Diversification and free-riding in monitoring," Journal of Financial Intermediation, 2007, 16 (3), $425-451$.

Chernenko, Sergey and Adi Sunderam, "The real consequences of market segmentation," The Review of Financial Studies, 2011, 25 (7), 2041-2069.

Cornaggia, Jess and Kimberly J Cornaggia, "Estimating the costs of issuer-paid credit ratings," The Review of Financial Studies, 2013, 26 (9), 2229-2269.

Degryse, Hans and Steven Ongena, "Distance, lending relationships, and competition," The Journal of Finance, 2005, 60 (1), 231-266. 
DeYoung, Robert, Dennis Glennon, and Peter Nigro, "Borrower-lender distance, credit scoring, and loan performance: Evidence from informational-opaque small business borrowers," Journal of Financial Intermediation, 2008, 17 (1), 113-143.

Diamond, Douglas W, "Financial intermediation and delegated monitoring," The review of economic studies, 1984, 51 (3), 393-414.

Faulkender, Michael and Mitchell A Petersen, "Does the source of capital affect capital structure?," The Review of Financial Studies, 2005, 19 (1), 45-79.

Fraisse, Henri, Mathias Lé, and David Thesmar, "The real effects of bank capital requirements," 2015.

Goel, Anand M and Anjan V Thakor, "Information reliability and welfare: A theory of coarse credit ratings," Journal of Financial Economics, 2015, 115 (3), 541-557.

Gropp, Reint, Thomas Mosk, Steven Ongena, and Carlo Wix, "Banks Response to Higher Capital Requirements: Evidence from a Quasi-Natural Experiment," The Review of Financial Studies, 2016.

Hauswald, Robert and Robert Marquez, "Information technology and financial services competition," The Review of Financial Studies, 2003, 16 (3), 921-948.

_ and _ , "Competition and strategic information acquisition in credit markets," The Review of Financial Studies, 2006, 19 (3), 967-1000.

Hombert, Johan and Adrien Matray, "The real effects of lending relationships on innovative firms and inventor mobility," The Review of Financial Studies, 2016, 30 (7), 2413-2445.

Jiang, John Xuefeng, Mary Harris Stanford, and Yuan Xie, "Does it matter who pays for bond ratings? Historical evidence," Journal of Financial Economics, 2012, 105 (3), 607-621.

Jiménez, Gabriel, Jose A Lopez, and Jesús Saurina, "Empirical analysis of corporate credit lines," The Review of Financial Studies, 2009, 22 (12), 5069-5098.

Kliger, Doron and Oded Sarig, "The information value of bond ratings," The Journal of Finance, 2000, 55 (6), 2879-2902.

Lee, Sang Whi and Donald J Mullineaux, "Monitoring, financial distress, and the structure of commercial lending syndicates," Financial management, 2004, pp. 107-130.

Lemmon, Michael and Michael R Roberts, "The response of corporate financing and investment to changes in the supply of credit," Journal of Financial and Quantitative Analysis, 2010, $45(3), 555-587$.

Mésonnier, Jean-Stéphane, Charles O'Donnell, and Olivier Toutain, "The Interest of Being Eligible," Working Paper 636, Banque de France 2017.

Mester, Loretta J, Leonard I Nakamura, and Micheline Renault, "Transactions accounts and loan monitoring," The Review of Financial Studies, 2006, 20 (3), 529-556.

Norden, Lars and Martin Weber, "Credit line usage, checking account activity, and default risk of bank borrowers," The Review of Financial Studies, 2010, 23 (10), 3665-3699. 
Schenone, Carola, "Lending relationships and information rents: Do banks exploit their information advantages?," The Review of Financial Studies, 2009, 23 (3), 1149-1199.

Stahl, Konrad and Roland Strausz, "Certification and market transparency," The Review of Economic Studies, 2017, 84 (4), 1842-1868.

Sufi, Amir, "The real effects of debt certification: Evidence from the introduction of bank loan ratings," The Review of Financial Studies, 2007, 22 (4), 1659-1691.

Sutherland, Andrew, "Does credit reporting lead to a decline in relationship lending? Evidence from information sharing technology," Journal of Accounting and Economics, 2018.

Tang, Tony T, "Information asymmetry and firms credit market access: Evidence from Moody's credit rating format refinement," Journal of Financial Economics, 2009, 93 (2), $325-351$.

Xia, Han, "Can investor-paid credit rating agencies improve the information quality of issuerpaid rating agencies?," Journal of Financial Economics, 2014, 111 (2), 450-468. 


\section{Figures}

Figure 1

The rating scale reform of April 2004

This figure depicts the rating scales before and after April 2004, the official date at which the reform of the rating scale was implemented. The old and the new rating classifications are presented by increasing default probability from left to right.

\section{The credit rating scale before April 2004}

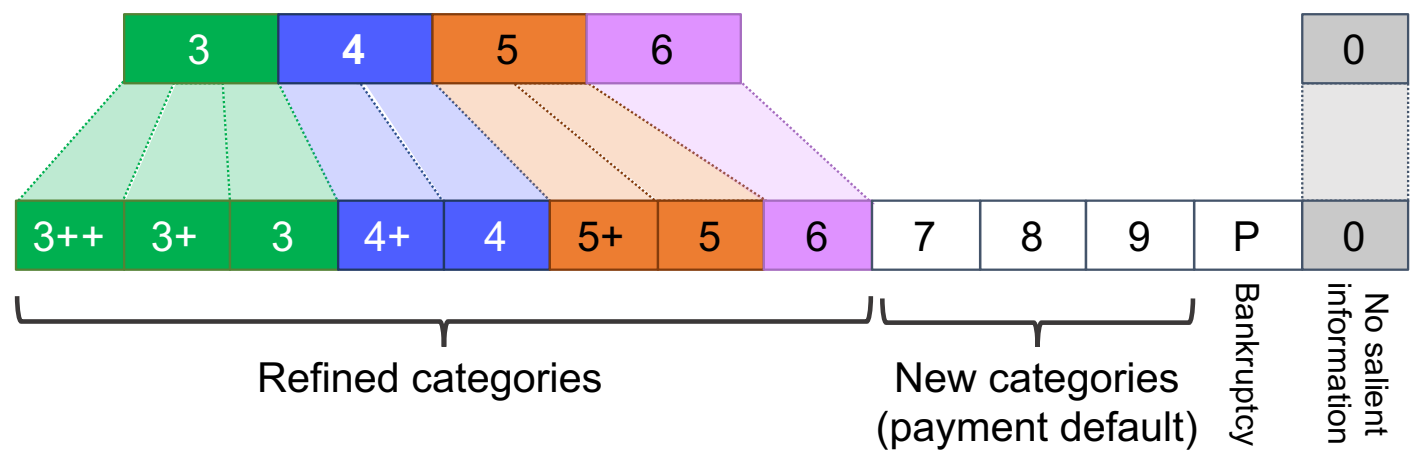

Sound debtors / low probability of default

Weak debtors / high probability of default

\section{The credit rating scale after April 2004}




\section{Figure 2}

Flow of bank loans around reform

This figure plots the average residuals in the quarterly flow of bank loans depending on the distance from the implementation of the reform. The residuals are obtained with respect to firm and industry x quarter FEs, which control for time-invariant firm unobservables and industry dynamics. The policy change is identified by the vertical red line between quarter 0 and quarter 1. Firms are grouped depending on whether after the policy change receive the rating surprise or have no rating surprise. The figure also reports the $95 \%$ confidence bounds.

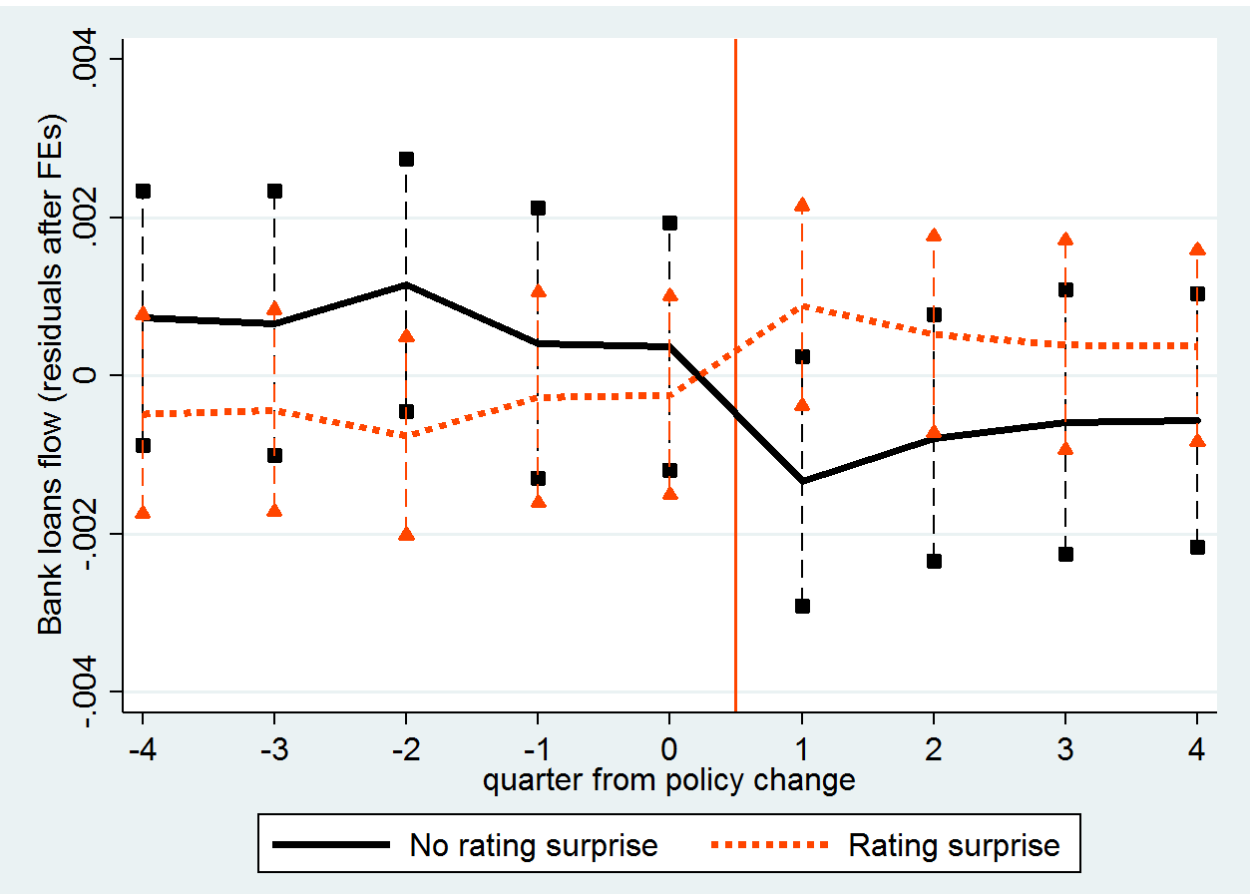




\section{Figure 3}

\section{Loan rate around reform}

This figure plots the average residuals in the loan rate paid depending on the distance from the implementation of the reform. The residuals are obtained with respect to firm and industry x year FEs, which control for time-invariant firm unobservables and industry dynamics. The policy change is identified by the vertical red line between year 0 and year 1 . Firms are grouped depending on whether after the policy change receive the rating surprise or have no rating surprise. The figure also reports the $95 \%$ confidence bounds.

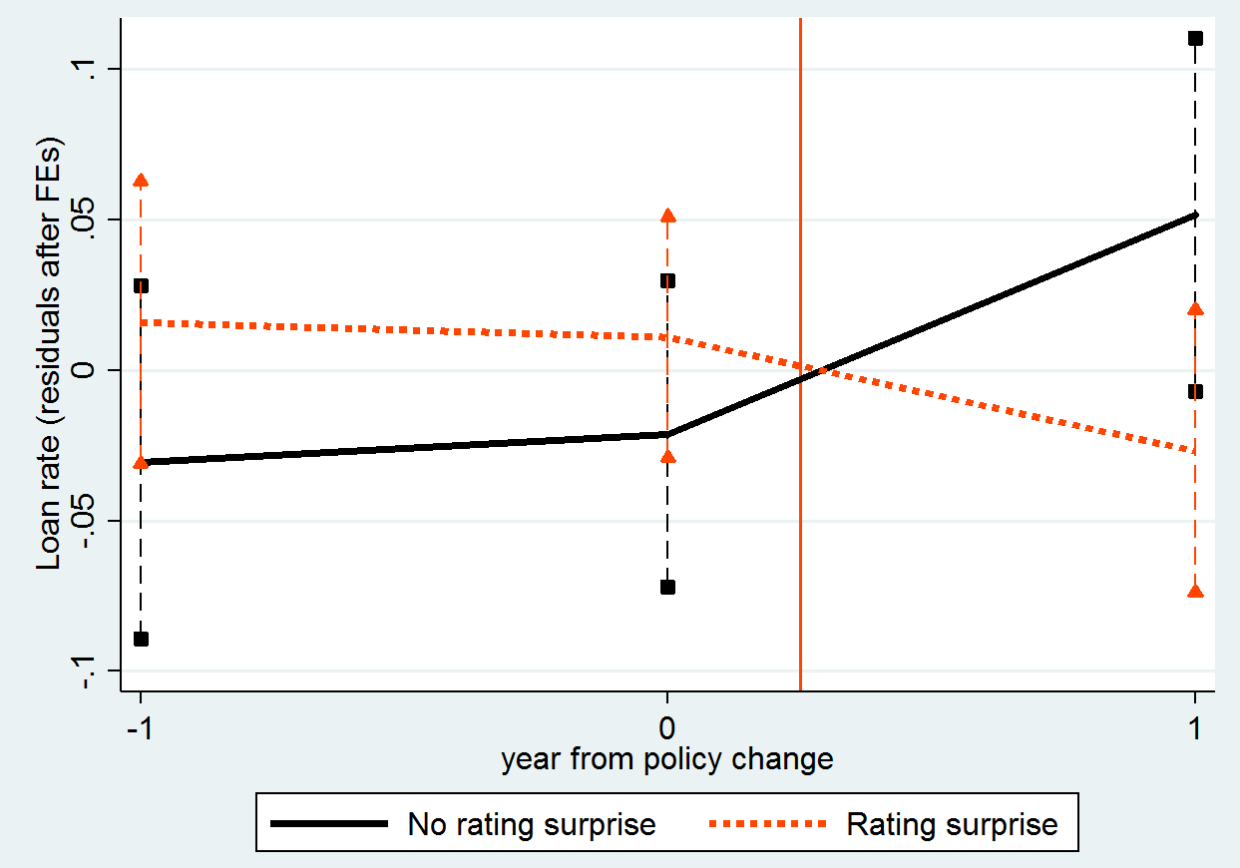




\section{Tables}

Table I

Firms' summary statistics

This table displays summary statistics for the firms in the sample, by rating class. The quarterly flows of bank loans, in total or distinguished by maturity (up to 1 year or above), and the 'New bank relationship' dummy are derived from the credit register data. The flows are computed as quarterly changes in the amount of interest and are normalized by lagged total assets. The dummy defines if a firm starts a new bank relationship in a given quarter. The unit of observation of the panel is firm-quarter, and firms are tracked from five quarters before the policy change to four quarters after it. All other variables are derived from the balance sheet data. The flows are obtained as yearly changes in the amount of interest, and are normalized by lagged total assets. In this case, the unit of observation of the panel is firm-year. Firms are tracked from two balance sheets before the policy change to the first balance sheet after it. In both panels, each firm belongs to the same rating class until the implementation of the reform. When the reform is implemented some firms receive the rating surprise, while others do not.

\begin{tabular}{|c|c|c|c|c|c|}
\hline & \multicolumn{5}{|c|}{ Rating class: 3} \\
\hline & $\mathrm{N}$ & Mean & St.Dev. & 5th pctile & 95th pctile \\
\hline Bank loans (norm. quarterly flow) & 54,024 & -0.001 & 0.043 & -0.057 & 0.074 \\
\hline Bank loans up to 1yr mat. (norm. quart. flow) & 54,024 & 0.000 & 0.028 & -0.035 & 0.036 \\
\hline Bank loans more than 1yr mat. (norm. quart. flow) & 54,024 & -0.001 & 0.022 & -0.023 & 0.036 \\
\hline New bank relationship & 54,024 & 0.050 & 0.218 & 0.000 & 1.000 \\
\hline Bank loans (norm. yearly flow) & 34,501 & -0.001 & 0.045 & -0.058 & 0.075 \\
\hline Loan rate (in $\mathrm{pp}$ ) & 23,542 & 6.019 & 3.652 & 1.373 & 13.924 \\
\hline Equity (norm. yearly flow) & 34,501 & 0.035 & 0.064 & -0.055 & 0.143 \\
\hline Cash (norm. yearly flow) & 34,501 & 0.020 & 0.098 & -0.136 & 0.195 \\
\hline Tot. investment (norm., yearly) & 34,501 & 0.002 & 0.044 & -0.051 & 0.079 \\
\hline Dividends paid (norm., yearly) & 34,501 & 0.061 & 0.066 & 0.000 & 0.200 \\
\hline Total assets (in M EUR) & 34,501 & 8.623 & 136.439 & 0.553 & 14.300 \\
\hline Return on Assets (yearly) & 34,385 & 0.198 & 0.096 & 0.069 & 0.381 \\
\hline Equity / Total assets & 34,500 & 0.526 & 0.178 & 0.249 & 0.825 \\
\hline \multirow[t]{3}{*}{ Banque de France's score } & 34,461 & 0.916 & 1.128 & 0.210 & 2.360 \\
\hline & \multicolumn{5}{|c|}{ Rating class: 4} \\
\hline & $\mathrm{N}$ & Mean & St.Dev. & 5th pctile & 95th pctile \\
\hline Bank loans (norm. quarterly flow) & 33,086 & -0.001 & 0.065 & -0.103 & 0.119 \\
\hline Bank loans up to $1 y r$ mat. (norm. quart. flow) & 33,086 & 0.001 & 0.051 & -0.085 & 0.090 \\
\hline Bank loans more than 1yr mat. (norm. quart. flow) & 33,086 & -0.002 & 0.026 & -0.030 & 0.043 \\
\hline New bank relationship & 33,086 & 0.070 & 0.256 & 0.000 & 1.000 \\
\hline Bank loans (norm. yearly flow) & 10,183 & -0.003 & 0.066 & -0.095 & 0.118 \\
\hline Loan rate (in pp) & 7,862 & 6.531 & 3.940 & 1.563 & 15.000 \\
\hline Equity (norm. yearly flow) & 10,183 & 0.017 & 0.048 & -0.052 & 0.093 \\
\hline Cash (norm. yearly flow) & 10,183 & 0.006 & 0.083 & -0.124 & 0.159 \\
\hline Tot. investment (norm., yearly) & 10,183 & -0.001 & 0.047 & -0.062 & 0.086 \\
\hline Dividends paid (norm., yearly) & 10,183 & 0.028 & 0.054 & 0.000 & 0.151 \\
\hline Total assets (in M EUR) & 10,183 & 6.293 & 100.890 & 0.405 & 11.801 \\
\hline Return on Assets (yearly) & 10,159 & 0.116 & 0.089 & 0.015 & 0.285 \\
\hline Equity / Total assets & 10,183 & 0.330 & 0.167 & 0.112 & 0.667 \\
\hline \multirow[t]{3}{*}{ Banque de France's score } & 10,170 & 2.677 & 3.173 & 0.370 & 8.290 \\
\hline & \multicolumn{5}{|c|}{ Rating class: 5} \\
\hline & $\mathrm{N}$ & Mean & St.Dev. & 5th pctile & 95th pctile \\
\hline Bank loans (norm. quarterly flow) & 34,298 & -0.008 & 0.069 & -0.120 & 0.119 \\
\hline Bank loans up to 1yr mat. (norm. quart. flow) & 34,298 & 0.001 & 0.055 & -0.096 & 0.098 \\
\hline Bank loans more than 1yr mat. (norm. quart. flow) & 34,298 & -0.006 & 0.026 & -0.035 & 0.036 \\
\hline New bank relationship & 34,298 & 0.063 & 0.243 & 0.000 & 1.000 \\
\hline Bank loans (norm. yearly flow) & 5,959 & -0.015 & 0.082 & -0.130 & 0.137 \\
\hline Loan rate (in pp) & 4,956 & 6.908 & 3.915 & 1.852 & 15.385 \\
\hline Equity (norm. yearly flow) & 5,959 & 0.009 & 0.057 & -0.081 & 0.089 \\
\hline Cash (norm. yearly flow) & 5,959 & -0.000 & 0.062 & -0.099 & 0.101 \\
\hline Tot. investment (norm., yearly) & 5,959 & -0.007 & 0.052 & -0.080 & 0.079 \\
\hline Dividends paid (norm., yearly) & 5,959 & 0.018 & 0.043 & 0.000 & 0.113 \\
\hline Total assets (in M EUR) & 5,959 & 4.265 & 55.515 & 0.360 & 10.116 \\
\hline Return on Assets (yearly) & 5,943 & 0.086 & 0.092 & -0.045 & 0.242 \\
\hline Equity / Total assets & 5,927 & 0.179 & 0.178 & 0.004 & 0.514 \\
\hline Banque de France's score & 5,938 & 6.120 & 6.582 & 0.600 & 18.610 \\
\hline
\end{tabular}


Table II

The effect of the rating surprise on the flow of bank loans

This table shows the effect of the rating surprise on the quarterly flow of bank loans, also distinguishing by the maturity of the loans. The flows are obtained as quarterly changes in the stock of interest, and are normalized by lagged total assets. Firms are tracked from five quarters before the policy change to four quarters after it. When the reform is implemented some firms receive the rating surprise while others do not. 'rating surprise' measures the impact on the flow of bank loans of receiving the rating surprise relative to not receiving it. Standard errors are clustered at the firm level, and t-statistics are in parenthesis. Statistical significance: ${ }^{*} p<0.10,{ }^{* *} p<0.05,{ }^{* * *} p<0.01$.

\begin{tabular}{lccc}
\hline Depedent Variable: & & & \\
& $(1)$ & $(2)$ & \\
& Bank loans \\
& (norm. quarterly flow) & $\begin{array}{c}\text { Bank loans up to 1yr mat. } \\
\text { (norm. quarterly flow) }\end{array}$ & $\begin{array}{c}\text { Bank loans more than 1yr mat. } \\
\text { (norm. quarterly flow) }\end{array}$ \\
\hline rating surprise & $0.003^{* * *}$ & $0.001^{* * *}$ & $0.001^{* * *}$ \\
& $(4.57)$ & $(2.76)$ & $(3.28)$ \\
\hline Firm FE & Yes & Yes & Yes \\
3 digit industry x Quarter FE & Yes & Yes & Yes \\
Rating class x Quarter FE & Yes & Yes & 121,408 \\
Observations & 121,408 & 121,408 & 0.18 \\
$R^{2}$ & 0.14 & 0.09 & 18 \\
\hline
\end{tabular}


Table III

The effect of the rating surprise depending on the bank's screening and monitoring cost

This table shows the effect of the rating surprise on the quarterly flow of bank loans as a function of the bank's before-the-reform screening and monitoring cost. The flows are obtained as quarterly changes in the stock of bank debt, and are normalized by lagged total assets. Firms are tracked from five quarters before the policy change to four quarters after it. When the reform is implemented some firms receive the rating surprise while others do not. The effect of the rating surprise is differentiated depending on proxies for the bank's screening and monitoring cost right before the reform. 'bank branch is located in a diff. town' indicates if the firm is headquartered in a different town than where the bank branch is located. ' $N$ products with the bank' is the number of loan products (e.g., leasing contracts, mortgages, etc.) that the firm has with the bank. Standard errors are clustered at the firm level, and t-statistics are in parenthesis. Statistical significance: ${ }^{*} p<0.10,{ }^{* *} p<0.05,{ }^{* * *} p<0.01$.

\begin{tabular}{|c|c|c|}
\hline \multicolumn{3}{|l|}{ Depedent Variable: } \\
\hline & $\begin{array}{c}\text { (1) } \\
\text { Bank loans } \\
\text { (norm. quarterly flow) }\end{array}$ & $\begin{array}{c}(2) \\
\text { Bank loans } \\
\text { (norm. quarterly flow) }\end{array}$ \\
\hline rating surprise & $\begin{array}{c}0.001^{* * *} \\
(3.03)\end{array}$ & $\begin{array}{c}0.003^{* * *} \\
(9.24)\end{array}$ \\
\hline — $\mathrm{x}$ bank branch is located in a diff. town & $\begin{array}{c}0.007^{* * *} \\
(2.73)\end{array}$ & \\
\hline$-\mathrm{x} N$ products with the bank & & $\begin{array}{c}-0.001^{* * *} \\
(-8.36)\end{array}$ \\
\hline bank branch is located in a diff. town & $\begin{array}{l}0.007 \\
(0.71)\end{array}$ & \\
\hline $\mathrm{N}$ products with the bank & & $\begin{array}{c}0.001^{* * *} \\
(6.48)\end{array}$ \\
\hline Firm FE & Yes & Yes \\
\hline Bank x Quarter FE & Yes & Yes \\
\hline 3 digit industry $\mathrm{x}$ Quarter $\mathrm{FE}$ & Yes & Yes \\
\hline Rating class x Quarter FE & Yes & Yes \\
\hline Observations & 270,384 & 255,598 \\
\hline$R^{2}$ & 0.11 & 0.12 \\
\hline
\end{tabular}


Table IV

The effect of the rating surprise depending on

\section{the bank's incentives to screen and monitor the firm}

This table shows the effect of the rating surprise on the quarterly flow of bank loans as a function of the bank's before-the-reform incentives to screen and monitor the firm. The flows are obtained as quarterly changes in the stock of bank debt, and are normalized by lagged total assets. Firms are tracked from five quarters before the policy change to four quarters after it. When the reform is implemented some firms receive the rating surprise while others do not. The effect of the rating surprise is differentiated depending on proxies for the bank's incentives to screen the firm right before the reform. 'bank importance in the pool of lenders' is the proportion of bank debt borrowed from a particular bank over the total borrowed. 'main bank' is a dummy variable that equals 1 when the previous proportion reaches the highest level across the relationships the firm has. Finally, 'firm importance in the pool of borrowers' denotes the proportion of bank debt that the firm obtained relative to the total amount of debt lent by the bank. Standard errors are clustered at the firm level, and t-statistics are in parenthesis. Statistical significance: ${ }^{*} p<0.10,{ }^{* *} p<0.05, * * * p<0.01$.

\begin{tabular}{|c|c|c|c|}
\hline \multicolumn{4}{|l|}{ Depedent Variable: } \\
\hline & $\begin{array}{c}(1) \\
\text { Bank loans } \\
\text { (norm. quarterly flow) }\end{array}$ & $\begin{array}{c}(2) \\
\text { Bank loans } \\
\text { (norm. quarterly flow) }\end{array}$ & $\begin{array}{c}(3) \\
\text { Bank loans } \\
\text { (norm. quarterly flow) }\end{array}$ \\
\hline rating surprise & $\begin{array}{c}0.003^{* * *} \\
(12.35)\end{array}$ & $\begin{array}{c}0.002^{* * *} \\
(8.74)\end{array}$ & $\begin{array}{c}0.001^{* * *} \\
(4.21)\end{array}$ \\
\hline - $\mathrm{x}$ bank imp. in the pool of lenders & $\begin{array}{c}-0.009^{* * *} \\
(-12.88)\end{array}$ & & \\
\hline - $\mathrm{x}$ main bank & & $\begin{array}{c}-0.004^{* * *} \\
(-12.91)\end{array}$ & \\
\hline - $\mathrm{x}$ firm imp. in the pool of borrowers & & & $\begin{array}{l}-0.005^{* * *} \\
(-6.73)\end{array}$ \\
\hline bank imp. in the pool of lenders & $\begin{array}{c}0.002^{* * *} \\
(4.54)\end{array}$ & & \\
\hline main bank & & $\begin{array}{l}0.001^{* * *} \\
(5.83)\end{array}$ & \\
\hline firm imp. in the pool of borrowers & & & $\begin{array}{l}0.000 \\
(1.10)\end{array}$ \\
\hline Firm FE & Yes & Yes & Yes \\
\hline Bank x Quarter FE & Yes & Yes & Yes \\
\hline 3 digit industry $\mathrm{x}$ Quarter FE & Yes & Yes & Yes \\
\hline Rating class x Quarter FE & Yes & Yes & Yes \\
\hline Observations & 216,750 & 216,750 & 253,577 \\
\hline$R^{2}$ & 0.09 & 0.09 & 0.12 \\
\hline
\end{tabular}


Table V

The effect of the rating surprise on the probability to start a new bank relationship

This table shows the effect of the rating surprise on the probability to start a new bank relationship. The dependent variable 'New bank rel.' indicates whether the firm starts a new bank relationship in the quarter. Firms are tracked from five quarters before the policy change to four quarters after it. When the reform is implemented some firms receive the rating surprise while others do not. 'rating surprise' measures the impact on the probability to start a new bank relationship of receiving the rating surprise relative to not receiving it. The column on the left reports the marginal effects obtained with a Conditional Logit estimation, while the column on the right the effects obtained with a linear probability model (LPM). The standard errors in the column on the right are clustered at the firm level. T-statistics are in parenthesis. Statistical significance: ${ }^{*} p<0.10,{ }^{* *} p<0.05, * * * p<0.01$.

\begin{tabular}{lcc}
\hline Depedent Variable: & & \\
\hline & $(1)$ & $(2)$ \\
& $\begin{array}{c}\text { New bank rel. } \\
\text { (Logit) }\end{array}$ & $\begin{array}{c}\text { New bank rel. } \\
(\text { LPM })\end{array}$ \\
\hline rating surprise & $0.036^{* * *}$ & $0.007^{* * *}$ \\
& $(2.83)$ & $(2.63)$ \\
\hline Firm FE & Yes & Yes \\
Quarter FE & Yes & No \\
3 digit industry x Quarter FE & No & Yes \\
Rating class x Quarter FE & No & Yes \\
Observations & 44,176 & 121,408 \\
$R^{2}$ & & 0.18 \\
\hline
\end{tabular}


Table VI

The effect of the rating surprise on the cost of debt and funding mix:

Difference-in-Differences estimates

This table shows the effect of the rating surprise on the cost of debt and funding mix, estimated using the baseline difference-in-differences methodology. The flows of bank loans and equity are obtained as yearly changes in the stocks, and are normalized by lagged total assets. Firms are tracked from two balance sheets before the policy change to the first balance sheet after it. When the reform is implemented some firms receive the rating surprise while others do not. 'rating surprise' measures the impact on the variable of interest of receiving the rating surprise relative to not receiving it. Standard errors are clustered at the firm level, and t-statistics are in parenthesis. Statistical significance: ${ }^{*} p<0.10,{ }^{* *}$ $p<0.05,{ }^{* * *} p<0.01$.

\begin{tabular}{lccc}
\hline Depedent Variable: & & & \\
\hline & $(1)$ & $(2)$ & $(3)$ \\
& $\begin{array}{c}\text { Bank loans } \\
\text { (norm. yearly flow) }\end{array}$ & $\begin{array}{c}\text { Loan rate } \\
\text { (in pp) }\end{array}$ & $\begin{array}{c}\text { Equity } \\
\text { (norm. yearly flow) }\end{array}$ \\
\hline rating surprise & $0.009^{* * *}$ & $-0.156^{* * *}$ & $-0.013^{* * *}$ \\
& $(7.02)$ & $(-2.67)$ & $(-11.25)$ \\
\hline Firm FE & Yes & Yes & Yes \\
3 digit industry x Period FE & Yes & Yes & Yes \\
Rating class x Quarter FE & Yes & Yes & Yes \\
Observations & 50,643 & 34,668 & 50,643 \\
$R^{2}$ & 0.35 & 0.74 & 0.58 \\
\hline
\end{tabular}

Table VII

The effect of the rating surprise on the employment of funds: Difference-in-Differences estimates

This table shows the effect of the rating surprise on the flow of cash, investment, and the dividends paid, estimated using the baseline difference-in-differences methodology. All variables are normalized by lagged total assets. Firms are tracked from two balance sheets before the policy change to the first balance sheet after it. Until the reform, each firm has constant fundamentals. When the reform is implemented some firms receive the rating surprise while others do not. 'rating surprise' measures the impact on the variable of interest of receiving the rating surprise relative to not receiving it. Standard errors are clustered at the firm level, and t-statistics are in parenthesis. Statistical significance: $* p<0.10, * *$ $p<0.05, * * * p<0.01$.

\begin{tabular}{lccc}
\hline Depedent Variable: & & & \\
& $(1)$ & $(2)$ & $(3)$ \\
& Cash & $\begin{array}{c}(3) \\
\text { Tot. investment } \\
\text { (norm., yearly) }\end{array}$ & $\begin{array}{c}\text { Dividends paid } \\
\text { (norm., yearly) }\end{array}$ \\
\hline rating surprise & $-0.006^{* * *}$ & $0.006^{* * *}$ & $0.006^{* * *}$ \\
& $(-3.02)$ & $(5.61)$ & $(8.83)$ \\
\hline Firm FE & Yes & Yes & Yes \\
3 digit industry x Period FE & Yes & Yes & Yes \\
Rating class x Quarter FE & Yes & Yes & Yes \\
Observations & 50,643 & 50,643 & 50,643 \\
$R^{2}$ & 0.29 & 0.39 & 0.81 \\
\hline
\end{tabular}




\section{Table VIII}

Differences between firms that later receive the rating surprise and firms that later do not This table compares the financial conditions of firms that later receive the rating surprise and firms that do not, right before the implementation of the reform. The comparison is repeated within each rating class. The sample includes the firms that are employed in the difference-in-difference analysis. Standard deviations are in parenthesis. Stars indicate the statistical significance: ${ }^{*} p<0.10,{ }^{* *} p<0.05,{ }^{* * *} p<0.01$.

\begin{tabular}{|c|c|c|c|}
\hline & \multicolumn{3}{|c|}{ Rating class: 3} \\
\hline & $\begin{array}{l}\text { No future } \\
\text { rating surprise }\end{array}$ & $\begin{array}{l}\text { Future rating } \\
\text { surprise }\end{array}$ & $\begin{array}{l}\text { Difference wrt } \\
\text { no rat. surprise }\end{array}$ \\
\hline Equity / Total assets & $\begin{array}{c}0.37 \\
(0.13)\end{array}$ & $\begin{array}{c}0.59 \\
(0.15)\end{array}$ & $\begin{array}{c}0.22^{* * *} \\
(0.00)\end{array}$ \\
\hline Tang. assets / Total assets & $\begin{array}{c}0.14 \\
(0.13)\end{array}$ & $\begin{array}{c}0.12 \\
(0.11)\end{array}$ & $\begin{array}{c}-0.03^{* * *} \\
(0.00)\end{array}$ \\
\hline Cash / Total assets & $\begin{array}{c}0.20 \\
(0.16)\end{array}$ & $\begin{array}{c}0.31 \\
(0.19)\end{array}$ & $\begin{array}{c}0.10^{* * *} \\
(0.00)\end{array}$ \\
\hline Return on Assets & $\begin{array}{c}0.17 \\
(0.09)\end{array}$ & $\begin{array}{c}0.21 \\
(0.09)\end{array}$ & $\begin{array}{c}0.04^{* * *} \\
(0.00)\end{array}$ \\
\hline Banque de France's score & $\begin{array}{l}1.37 \\
(1.18)\end{array}$ & $\begin{array}{c}0.62 \\
(0.60)\end{array}$ & $\begin{array}{c}-0.75^{* * *} \\
(0.02)\end{array}$ \\
\hline \multirow[t]{3}{*}{ log Total assets } & $\begin{array}{l}7.60 \\
(1.02)\end{array}$ & $\begin{array}{c}7.64 \\
(0.99)\end{array}$ & $\begin{array}{c}0.04^{* *} \\
(0.02)\end{array}$ \\
\hline & \multicolumn{3}{|c|}{ Rating class: 4} \\
\hline & $\begin{array}{l}\text { No future } \\
\text { rating surprise }\end{array}$ & $\begin{array}{l}\text { Future rating } \\
\text { surprise }\end{array}$ & $\begin{array}{l}\text { Difference wrt } \\
\text { no rat. surprise }\end{array}$ \\
\hline Equity / Total assets & $\begin{array}{c}0.32 \\
(0.18)\end{array}$ & $\begin{array}{c}0.34 \\
(0.15)\end{array}$ & $\begin{array}{c}0.02^{* * *} \\
(0.01)\end{array}$ \\
\hline Tang. assets / Total assets & $\begin{array}{c}0.11 \\
(0.12)\end{array}$ & $\begin{array}{l}0.15 \\
(0.14)\end{array}$ & $\begin{array}{c}0.04^{* * *} \\
(0.00)\end{array}$ \\
\hline Cash / Total assets & $\begin{array}{c}0.14 \\
(0.15)\end{array}$ & $\begin{array}{c}0.13 \\
(0.14)\end{array}$ & $\begin{array}{l}-0.01 \\
(0.01)\end{array}$ \\
\hline Return on Assets & $\begin{array}{c}0.07 \\
(0.06)\end{array}$ & $\begin{array}{c}0.14 \\
(0.09)\end{array}$ & $\begin{array}{c}0.07^{* * *} \\
(0.00)\end{array}$ \\
\hline Banque de France's score & $\begin{array}{c}2.80 \\
(3.17)\end{array}$ & $\begin{array}{c}2.08 \\
(1.89)\end{array}$ & $\begin{array}{c}-0.72^{* * *} \\
(0.10)\end{array}$ \\
\hline \multirow[t]{3}{*}{ log Total assets } & $\begin{array}{c}7.43 \\
(1.11)\end{array}$ & $\begin{array}{c}7.31 \\
(0.98)\end{array}$ & $\begin{array}{c}-0.12^{* * *} \\
(0.04)\end{array}$ \\
\hline & \multicolumn{3}{|c|}{ Rating class: 5} \\
\hline & $\begin{array}{l}\text { No future } \\
\text { rating surprise }\end{array}$ & $\begin{array}{l}\text { Future rating } \\
\text { surprise }\end{array}$ & $\begin{array}{c}\text { Difference wrt } \\
\text { no rat. surprise }\end{array}$ \\
\hline Equity / Total assets & $\begin{array}{c}0.13 \\
(0.20)\end{array}$ & $\begin{array}{c}0.20 \\
(0.16)\end{array}$ & $\begin{array}{c}0.06^{* * *} \\
(0.01)\end{array}$ \\
\hline Tang. assets / Total assets & $\begin{array}{c}0.14 \\
(0.15)\end{array}$ & $\begin{array}{c}0.18 \\
(0.20)\end{array}$ & $\begin{array}{c}0.04^{* * *} \\
(0.01)\end{array}$ \\
\hline Cash / Total assets & $\begin{array}{c}0.07 \\
(0.10)\end{array}$ & $\begin{array}{c}0.06 \\
(0.09)\end{array}$ & $\begin{array}{l}-0.00 \\
(0.00)\end{array}$ \\
\hline Return on Assets & $\begin{array}{c}0.03 \\
(0.08)\end{array}$ & $\begin{array}{c}0.11 \\
(0.08)\end{array}$ & $\begin{array}{c}0.07^{* * *} \\
(0.00)\end{array}$ \\
\hline Banque de France's score & $\begin{array}{c}8.48 \\
(7.16)\end{array}$ & $\begin{array}{c}4.79 \\
(5.33)\end{array}$ & $\begin{array}{c}-3.69^{* * *} \\
(0.32)\end{array}$ \\
\hline log Total assets & $\begin{array}{c}7.30 \\
(1.15)\end{array}$ & $\begin{array}{c}7.25 \\
(0.95)\end{array}$ & $\begin{array}{l}-0.04 \\
(0.05)\end{array}$ \\
\hline
\end{tabular}


Table IX

The effect of the rating surprise on the cost of debt and funding mix: Propensity Score Matching estimates

This table shows the effect of the rating surprise on the changes in the normalized flows of bank loans and equity, and on the change in the loan rate, using a Propensity Score Matching methodology. We first obtain the change in the variables of interest that each firm experiences from the last year before the reform to the first after it. We then compute propensity scores based on the following firm characteristics in the last year before the reform: total assets in $\log$, equity to total assets, Banque de France's score, industry, and rating class. The matching procedure is done with replacement, which means that each firm that does not receive the rating surprise can be used as a neighbor for several 'treated' firms, which receive the surprise. We take the closest five firms not receiving the rating surprise as control for each treated firm receiving the surprise. We then study of effect of the 'rating surprise' on the outcome variables. Standard errors are robust, and t-statistics are in parenthesis. Statistical significance: ${ }^{*} p<0.10,{ }^{* *} p<0.05, * * * p<0.01$.

\begin{tabular}{lccc}
\hline \multicolumn{2}{l}{ Depedent Variable: } & & \\
\hline & $(1)$ & $(2)$ & $(3)$ \\
& Change in & Change in & Change in \\
bank loans & loan rate & equity \\
& $($ in pp) & (norm. flow) \\
\hline rating surprise & $0.003^{* *}$ & $-0.171^{* * *}$ & $-0.008^{* * *}$ \\
& $(2.07)$ & $(-3.15)$ & $(-6.56)$ \\
\hline Observations & 38,131 & 25,871 & 38,131 \\
\hline
\end{tabular}

Table X

The effect of the rating surprise on the employment of funds

Propensity Score Matching estimates

This table shows the effect of the rating surprise on the changes in the normalized flow of cash, investment, and dividends paid, using a Propensity Score Matching methodology. We first obtain the change in the variables of interest that each firm experiences from the last year before the reform to the first after it. We then compute propensity scores based on the following firm characteristics in the last year before the reform: total assets in log, equity to total assets, Banque de France's score, industry, and rating class. The matching procedure is done with replacement, which means that each firm that does not receive the rating surprise can be used as a neighbor for several 'treated' firms, which receive the surprise. We take the closest five firms not receiving the rating surprise as control for each treated firm receiving the surprise. We then study of effect of the 'rating surprise' on the outcome variables. Standard errors are robust, and t-statistics are in parenthesis. Statistical significance: ${ }^{*} p<0.10,{ }^{* *} p<0.05, * * * p<0.01$.

\begin{tabular}{lccc}
\hline \multicolumn{2}{l}{ Depedent Variable: } & & \\
\hline & $(1)$ & $(2)$ & $(3)$ \\
& Change in & Change in & Change in \\
& cash & tot. investment & dividends paid \\
& (norm. flow) & (normalized) & (normalized) \\
\hline rating surprise & $-0.012^{* * *}$ & $0.002^{* *}$ & $0.003^{* * *}$ \\
& $(-5.90)$ & $(2.15)$ & $(5.18)$ \\
\hline Observations & 38,131 & 38,131 & 38,131 \\
\hline
\end{tabular}

